\title{
Effects of Olive Cake and Cactus Cladodes as Alternative Feed Resources on Goat Milk Production and Quality
}

\author{
Samira El Otmani ${ }^{1,2, *}$, Youssef Chebli ${ }^{1,2}{ }^{\oplus}$, Mouad Chentouf ${ }^{2}{ }^{(}$, Jean-Luc Hornick ${ }^{1}(\mathbb{D}$ and \\ Jean-François Cabaraux ${ }^{1}$ (D) \\ 1 Department of Veterinary Management of Animal Resources, University of Liège, Avenue de Cureghem 6, \\ B43, 4000 Liège, Belgium; ychebli@doct.uliege.be (Y.C.); jlhornick@uliege.be (J.-L.H.); \\ jfcabaraux@uliege.be (J.-F.C.) \\ 2 National Institute of Agricultural Research (INRA), 78 Bd. Mohamed Ben Abdellah, Tangier 90010, Morocco; \\ mouad.chentouf@inra.ma \\ * Correspondence: selotmani@doct.uliege.be
}

Citation: El Otmani, S.; Chebli, Y.; Chentouf, M.; Hornick, J.; Cabaraux, J. Effects of Olive Cake and Cactus Cladodes as Alternative Feed Resources on Goat Milk Production and Quality. Agriculture 2021, 11, 3.

https://dx.doi.org/10.3390/ agriculture11010003

Received: 16 November 2020 Accepted: 21 December 2020 Published: 22 December 2020

Publisher's Note: MDPI stays neutral with regard to jurisdictional claims in published maps and institutional affiliations.

Copyright: (c) 2020 by the authors. Licensee MDPI, Basel, Switzerland. This article is an open access article distributed under the terms and conditions of the Creative Commons Attribution (CC BY) license (https: / / creativecommons.org/ licenses/by/4.0/).

\begin{abstract}
In the Mediterranean area, the olive cake (OC) and cactus cladodes (CC) are two alternative resources widely available that could be used for ruminants' feeding. The objective of this study was to evaluate the effects of OC and/or CC diet incorporation on the production performance and quality of goat milk. Forty-four lactating goats were randomly allocated to four groups. The control one (Co) received a conventional feed. Test groups $\left(\mathrm{T}_{\mathrm{OC}} ; \mathrm{T}_{\mathrm{CC}}\right.$ and $\mathrm{T}_{\mathrm{OC}+\mathrm{CC}}$ ) received $20 \% \mathrm{OC}, 30 \% \mathrm{CC}$, or $15 \%$ OC and 20\% CC, respectively, on concentrate dry matter basis. Over three months, milk production was evaluated, and samples were collected to analyze the milk quality. No significant differences were observed between control and test groups for daily milk production, yield, composition and acidity. In milk fat, OC incorporation increased C18:1n-9, mono-unsaturated (MUFA) and n-9 fatty acid (FA), and decreased 9t-C18:1 and poly-unsaturated FA (PUFA) $(p<0.05)$. Significantly highest contents of C15:0, C18:1n-9, and C21:0, and lowest levels of C4:0, 9t-C18:1, 6t-C18:2, C20:0, and PUFA were obtained with cactus cladodes administration $(p<0.05)$. The $\mathrm{T}_{\mathrm{OC}}+\mathrm{CC}$ diet reduced C4:0, 9t-C18:1, 6t-C18:2, C22:6n-3, and PUFA proportions, and increased C18:1n-9, MUFA/PUFA, and thrombogenic indexes. The incorporation rates of OC and CC that could reach $20 \%$ and $30 \%$, respectively, had no major negative effects on milk production performance, composition, and quality. Thus, they could be introduced in the diets of lactating goats.
\end{abstract}

Keywords: olive cake; cactus cladode; goat; milk production; milk quality; fatty acid

\section{Introduction}

In the Southern Mediterranean region, goat farming is widely practiced, especially in mountainous areas, due to this species' high adaptation ability [1]. In these systems, the goat diet is based essentially on forest rangelands that are composed of shrubs and oak trees. As many studies have confirmed, these rangelands are characterized by limited and low forage availability and seasonal variability, especially during drought periods and when goats' nutrient requirements are high (end of gestation, lactation, growth, and reproduction) [1-3]. These requirements of energy, nitrogen, and minerals increase greatly for transition goats (0-3 weeks after) when they give birth to more than one kid (most of the time twins and sometimes three kids) [4]. If dietary needs are unmet, young animals will have low growth performances [4]. Also, wrong rangelands utilization induces an overuse that causes a decrease of some palatable species and the dominance of unpalatable ones as well as the reduction of plant cover and pastoral feed availability [5-8]. To complete and satisfy the nutritional requirements of the animals, farmers are forced to incorporate conventional concentrates. Nevertheless, the use of these feedstuffs presents a concurrence for human food resources and an additional cost for farmers because their price fluctuates over the years, decreasing farmers' income $[3,9,10]$. As such, farmers should adopt other solutions 
to reduce cost by using available alternative feed resources [3]. The goat is known for its ability to digest feed containing high fiber and low protein contents [11]. The use of by-products in the goat diet could allow for a reduction of feed cost and, consequently an increase of farmers' income, a warranty of livestock production sustainability, and the preservation of pasture lands by reducing grazing intensity $[9,12]$.

In the Mediterranean region, mainly on the southern side, olive production is an ancestral activity occupying a large area. As a central component of the Mediterraneanstyle diet, the demand for olive oil is increasing all over the world. The olive oil production process generates large quantities of by-products such as olive cake (OC). This by-product is composed essentially of olive skin, pulp, stones, and vegetative water. Large amounts of this secondary product are frequently rejected in nature with a catastrophic impact on the environment [13]. The use of this by-product, known for its high fiber content, in ruminant nutrition could reduce the quantities rejected in nature and consequently could decrease their negative effect on the environment [14].

Also, in the Southern Mediterranean area, the cactus (Opuntia ficus indica) is a multipurpose and widely available shrub known among others for its adaptation capacity and as an evergreen forage for ruminants [15]. It is recommended as a feed and water source for small ruminants, especially in drought periods and areas because of its high water and energy content $[3,16]$.

Dairy goat farming has socio-economic and environmental significance in the Southern part of the Mediterranean area [17]. Consumers became aware of goat milk's importance in human nutrition, which is reflected in the increase of goat's milk product consumption (milk, cheese, and yogurt) [18]. Goat milk is characterized by a high digestibility due to its low curd tension, a high level of essential amino acids, such as threonine, isoleucine, lysine, cystine, tyrosine and valine, and its prevention of the milk allergy commonly reported with cow's milk consumption $[19,20]$.

Thus, the use of OC and CC in goats' diet as alternative feed resources permits a diversification of the livestock diet while reducing grazing pressure on pasture and an improved diet quality during shortage pasture periods. Their administration would increase breeders' income by reducing feed cost. The OC in goats' diet could valorize the large quantities of olive oil production by-products and decrease amounts rejected in nature, whereas CC could present a water source for flocks during dry seasons.

The alternative feed resources are known for their high content in fiber and secondary compounds as phenols and tannins that could affect milk yield and quality by influencing chemical composition and fatty acid (FA) precursors in rumen and blood [12,21].

Many studies have evaluated the effect of OC on cows and ewes. To our knowledge, there are few published studies on the effects of OC [22-24] and cactus cladodes (CC) in the lactating goat [25-27]. Furthermore, no studies have investigated the effect of the incorporation of OC and CC mixture in the goats' diet. In this context, this study aims to evaluate the effects of diets supplemented with OC and/or spiny CC on goat milk production performance and quality.

\section{Materials and Methods}

\subsection{Experimental Animals and Diets}

The study was performed in Bougdour experimental station belonging to the Agricultural Research Center of Tangier (INRA of Tangier-Morocco) at $35^{\circ} 67^{\prime} \mathrm{N}$ and $5^{\circ} 85^{\prime}$ W. Forty-four multiparous goats of "Beni Arouss" North Moroccan breed were divided into four homogeneous groups of 11 animals, that were comparable as means for parity $(3.4 \pm 0.21)$, as means for bodyweight $(32.25 \pm 0.50 \mathrm{~kg})$, and as for milk production in the early lactation $(750 \pm 0.46 \mathrm{~g})$. All animals were housed individually. From parturition until dry-off, these animals received a diet based on oat hay as fodder and supplemented with a concentrate complement that was different for each group; there was an adaptation period of 21 days before the beginning of the experiment. The conventional supplementation used by goat breeders in the region, composed of barley grain and fava bean, was distributed 
to the control group (Co). The three other groups were supplemented with fava bean plus OC and/or CC. These test groups received, respectively, on concentrate dry matter basis, either $20 \%$ of OC $\left(\mathrm{T}_{\mathrm{OC}}\right)$, or $30 \%$ of CC $\left(\mathrm{T}_{\mathrm{CC}}\right)$, or $15 \%$ of OC and $20 \%$ of CC $\left(\mathrm{T}_{\mathrm{OC}}+\mathrm{CC}\right)$. These proportions were used to obtain isoenergetic diet on the INRA recommendations basis (FUM) to satisfy lactating nutrient requirements. The OC and CC chemical composition and the ingredients and the chemical composition of the distributed diets are presented in Tables 1 and 2. The groups were fed two times a day as a complete ration ground and mixed, and the diets were distributed and adapted to allow $10 \%$ of orts. The goats had free access to fresh and clean water all the time. The offered OC was collected from a regional olive oil mill using the mechanical press extraction process, located in $34^{\circ} 79^{\prime} \mathrm{N}$, $5^{\circ} 61^{\prime} \mathrm{W}$, during the oil extraction period (November to January). The OC was air-dried in a greenhouse for a few days (3-7 days) and was conserved in plastic bags in hermetic conditions until the start of the experiment. The CC were provided from cactus shrubs present nearest to the experimental station. They were daily collected, the spines were removed manually, and the cladodes were cut to small slides of $9 \mathrm{~cm}^{2}$.

Table 1. Chemical composition of olive cake and cactus cladodes.

\begin{tabular}{ccc}
\hline Item & Olive Cake & Cactus Cladodes \\
\hline Dry matter (DM; g/kg) & 900 & 67 \\
Ash (g/kg DM) & 37 & 220 \\
Crude protein (CP; g/kg DM) & 92 & 71 \\
Ether extract (EE; g/kg DM) & 165 & 22 \\
Neutral detergent fiber (NDF; g/kg DM) & 641 & 446 \\
Acid detergent fiber (ADF; g/kg DM) & 507 & 173 \\
UFL (Unit/kg DM) & 0.43 & 0.75 \\
PDIN (g/kg DM) & 46 & 54 \\
PDIE (g/kg DM) & 42 & 48 \\
\hline
\end{tabular}

DM: Dry matter; UFL: Unit of forage for milk production (1 UFL = $1700 \mathrm{kcal} / 7.12 \mathrm{MJ})$; PDIN: Digestible proteins in the intestines allowed by nitrogen; PDIE: Digestible proteins in the intestines allowed by energy.

Table 2. Ingredients and chemical composition of the distributed diets.

\begin{tabular}{ccccc}
\hline Item & \multicolumn{5}{c}{ Diet $^{\mathbf{1}}$} \\
& Co & T $_{\text {OC }}$ & $\mathbf{T}_{\mathbf{C C}}$ & T $_{\mathbf{O C}}+\mathbf{C C}$ \\
\hline Diet ingredients (on DM basis) & & & & \\
Oat hay (\% TD) & 60 & 57 & 57 & 55 \\
Barley grain (\% Cc) & 15 & - & - & - \\
Olive cake (\% Cc) & - & 20 & - & 15 \\
Cactus cladodes (\% Cc) & - & - & 30 & 20 \\
Fava bean (\% Cc) & 83 & 78 & 68 & 63 \\
Vitamin-Mineral Supplement (\% Cc) & 2 & 2 & 2 & 2 \\
Nutrient composition & & & & \\
DM (g/kg) & 882 & 882 & 332 & 413 \\
Ash (g/kg DM) & 51 & 50 & 74 & 66 \\
CP (g/kg DM) & 143 & 144 & 134 & 134 \\
EE (g/kg DM) & 38 & 52 & 38 & 48 \\
NDF (g/kg DM) & 492 & 512 & 503 & 515 \\
ADF (g/kg DM) & 312 & 341 & 310 & 329 \\
UFL (unit/kg DM) & 0.8 & 0.8 & 0.8 & 0.8 \\
PDIN (g/kg DM) & 82 & 84 & 89 & 88 \\
PDIE (g/kg DM) & 75 & 63 & 69 & 67 \\
\hline
\end{tabular}

${ }^{1}$ Co: control diet; $\mathrm{T}_{\mathrm{OC}}$ : diet with $20 \%$ of olive cake; $\mathrm{T}_{\mathrm{CC}}$ : diet with $30 \%$ of cactus cladodes; $\mathrm{T}_{\mathrm{OC}}+\mathrm{CC}$ : diet with $15 \%$ of olive cake and $20 \%$ of cactus cladodes; ${ }^{2}$ TD: total diet; Cc: concentrate; DM: dry matter; CP: crude protein; EE: ether extract; NDF: Neutral detergent fiber; ADF: Acid detergent fiber; UFL: Unit of forage for milk production (1 UFL = $1700 \mathrm{kcal} / 7.12 \mathrm{MJ})$; PDIN: Digestible proteins in the intestines allowed by nitrogen; PDIE: Digestible proteins in the intestines allowed by energy. 


\subsection{Milk Production}

During the experiment, milk production was recorded and sampled fortnightly. The milk was weighed using a precision scale (with a sensitivity of $0.1 \mathrm{~g}$ ) and filtered; $250 \mathrm{~mL}$ of milk were sampled to determine the quality. Milk production per lactation was estimated using the Fleischmann method by multiplying the milk production by lactation duration according to the following formula [28]:

$$
\text { Milk yield }=I_{1} \times X_{1}+\left[\sum_{i=2}^{n}\left(\mathbf{I}_{i}-\mathbf{I}_{i-1}\right) \times \frac{\mathbf{X}_{i}+\mathbf{X}_{\mathbf{i}-1}}{2}\right]+I_{m} \times X_{n}
$$

where:

$\mathrm{I}_{1}$ : number of days between parturition and the first milk recording;

$\mathrm{X}_{1}$ : milk quantity produced at the first milk recording;

$\mathrm{I}_{\mathrm{i}}$ : number of days between the parturition and the i milk recording $(\mathrm{i}=2, \ldots, \mathrm{n})$;

$\mathrm{X}_{i}$ : milk quantity produced at the i milk recording $(\mathrm{i}=2, \ldots, \mathrm{n})$;

$\mathrm{I}_{\mathrm{m}}$ : number of days between the last milk recording and dry-off date;

$\mathrm{X}_{\mathrm{n}}$ : milk quantity produced at the last milk recording;

$\mathrm{n}=5$.

\subsection{Milk Analysis}

A quantity of $40 \mathrm{~mL}$ of milk was used to determine fat, protein, lactose, and solids nonfat contents by infra-red using MilkoScan ${ }^{\mathrm{TM}}$ Minor. The mineral matter (ash) was estimated by incinerating $5 \mathrm{~mL}$ of milk in a muffle furnace for $3 \mathrm{~h}$ at $550{ }^{\circ} \mathrm{C}$. Daily and per lactation fat, proteins, lactose, solids non-fat, and total solids were estimated by multiplying these average parameters, respectively, by daily and total milk production.

The chemical composition of milk was used to determine fat-corrected milk (FCM), energy-corrected milk (ECM), and the net energy of milk ( $\left.\mathrm{NE}_{\text {milk }}\right)$.

The FCM is a daily milk correction to $4 \%$ of fat and was calculated according to the following formula of NRC [29]:

$\operatorname{FCM}(4 \%)[\mathrm{g} /$ day $]=(0.4 \times$ milk production $[\mathrm{g} /$ day $]+(15 \times$ fat production $[\mathrm{g} /$ day $])$

The ECM that corrects milk considering fat, protein, and lactose was calculated according to the ALP [30] formula:

$\mathrm{ECM}[\mathrm{g} /$ day $]=$ Milk production $[\mathrm{g} /$ day $] \times(0.38 \times$ fat $[\%]+0.24 \times$ protein $[\%]+0.17 \times$ lactose $[\%]) / 3.14$

The $\mathrm{NE}_{\text {milk }}$ that presents the provided energy by milk was estimated using the NRC [31] following Equation:

$\mathrm{NE}_{\text {milk }}[\mathrm{Mcal} / \mathrm{kg}]=(0.0929 \times$ Fat $[\%])+(0.0547 \times$ Protein $[\%])+(0.0395 \times$ Lactose $[\%])$

Milk pH was performed using a pH-meter pen (HANNA HI 98120, Lingolsheim, France). Titratable acidity was determined by $10 \mathrm{~mL}$ milk titration using $0.1 \mathrm{~N}$ sodium hydroxide to evaluate lactic acid volume that represents $1 / 10$ of Dornic acidity, as described by Almeida and Dórea [32].

\subsection{Fatty Acid Profile}

The FA profile was estimated monthly (1st, 2nd, and 3rd months). Milk fat was extracted according to Barbano et al.'s [33] method using a petroleum ether. The FA methyl esters (FAMEs) were prepared by transmethylation described in the 969.33 method of AOAC [34]. One ml n-heptane containing FAMEs was recuperated in gas chromatograph (GC) vial and conserved in $-80{ }^{\circ} \mathrm{C}$ freezer until injection. The extract was injected in GC (Varian GC CP 3800) equipped with a flame ionization detector and a capillary column type CP-SIL88 capillary column $(100 \mathrm{~m} \times 0.25 \mathrm{~mm} \times 0.2 \mu \mathrm{m})$. The FA were identified by comparing with a standard analytical mixture of C4 to C24 FA (FAMEs Sigma-Aldrich, Darmstadt, 
Germany) that refers to 37 fatty acids. Detected FA were classified into 20 groups, ratios and indexes [34-36]:

Short-chain fatty acids $(\mathrm{SCFA})=\mathrm{C} 4: 0+\mathrm{C} 6: 0+\mathrm{C} 8: 0+\mathrm{C} 10: 0$,

Medium-chain fatty acids $(\mathrm{MCFA})=\mathrm{C} 11: 0+\mathrm{C} 12: 0+\mathrm{C} 13: 0+\mathrm{C} 14: 0+\mathrm{C} 14: 1$,

Long - chainfattyacids $(L C F A)=C 15: 0+C 15: 1+C 16: 0+C 16: 1+C 17: 0+C 17: 1+C 18: 0+9 t-C 18: 1+C 18: 1 n-9+$ $6 t-C 18: 2+C 18: 2 n-6+C 18: 3 n-6+C 18: 3 n-3+C 20: 0+C 20: 1+C 20: 2+C 20: 3 n-6+C 20: 3 n-3+C 20: 4 n-6+$

$C 21: 0+C 22: 1 n-9+C 22: 0+C 22: 2+C 22: 5 n-3+C 22: 6 n-3+C 23: 0+C 24: 0+C 24: 1$,

Saturatedfattyacids $(S F A)=C 4: 0+C 6: 0+C 8: 0+C 10: 0+C 11: 0+C 12: 0+C 13: 0+C 14: 0+C 15: 0+$

$C 16: 0+C 17: 0+C 18: 0+C 20: 0+C 21: 0+C 23: 0+C 22: 0+C 24: 0$,

Mono-unsaturated fatty acids $($ MUFA $)=\mathrm{C} 14: 1+\mathrm{C} 15: 1+\mathrm{C} 16: 1+\mathrm{C} 17: 1+9 \mathrm{t}-\mathrm{C} 18: 1+\mathrm{C} 18: 1 \mathrm{n}-9+\mathrm{C} 20: 1+\mathrm{C} 22: 1 \mathrm{n}-9+\mathrm{C} 24: 1$,

Polyunsaturated fattyacids $($ PUFA $)=6 t-C 18: 2+C 18: 2 n-6+C 18: 3 n-6+C 18: 3 n-3+C 20: 2+C 20: 3 n-6+$

$C 20: 3 n-3+C 20: 4 n-6+C 22: 2+C 22: 5 n-3+C 22: 6 n-3$,

Desirable fatty acids $($ DFA $)=$ C18:0 + PUFA + MUFA,

$\mathrm{n}-3=\mathrm{C} 18: 3 \mathrm{n}-3+\mathrm{C} 20: 3 \mathrm{n}-3+\mathrm{C} 20: 5 \mathrm{n}-3+\mathrm{C} 22: 6 \mathrm{n}-3$,

n-6 = 6t-C18:2 +C18:2n-6 +C18:3n-6 + C20:3n-6 + C20:4n-6,

$\mathrm{n}-9=9 \mathrm{t}-\mathrm{C} 18: 1+\mathrm{C} 18: 1 \mathrm{n}-9+\mathrm{C} 22: 1 \mathrm{n}-9$,

UFA/SFA ratio,

PUFA/SFA ratio,

MUFA/PUFA ratio,

n-6/n-3 ratio,

Atherogenicity index $(\mathrm{AI})=(\mathrm{C} 12: 0+(4 \times \mathrm{C} 14: 0)+\mathrm{C} 16: 0) /(\mathrm{MUFA}+\mathrm{PUFA})$,

Thrombogenic index $(\mathrm{TI})=(\mathrm{C} 14: 0+\mathrm{C} 16: 0+\mathrm{C} 18: 0) /[0.5($ MUFA $)+0.5(\mathrm{n}-6$ PUFA $)+3(\mathrm{n}-3$ PUFA $)+(\mathrm{n}-3$ PUFA $/ \mathrm{n}-6$ PUFA $)]$

$$
\begin{gathered}
(\mathrm{C} 18: 0+\mathrm{C} 18: 1) / \mathrm{C} 16: 0, \\
\Delta 9 \mathrm{C} 14=(\mathrm{C} 14: 1) /(\mathrm{C} 14: 1+\mathrm{C} 14: 0), \\
\Delta 9 \mathrm{C} 16=(\mathrm{C} 16: 1) /(\mathrm{C} 16: 1+\mathrm{C} 16: 0), \\
\Delta 9 \mathrm{C} 18=(\mathrm{C} 18: 1) /(\mathrm{C} 18: 1+\mathrm{C} 18: 0) .
\end{gathered}
$$

\subsection{Statistical Analysis}

Daily dairy production, milk composition, and FA data were evaluated according to PROC MIXED using SAS version 9.4 (SAS Inst. Inc., Cary, NC, USA) including the random effect of animals and the fix effects of diet $\left(\mathrm{Co} ; \mathrm{T}_{\mathrm{OC}} ; \mathrm{T}_{\mathrm{CC}} ; \mathrm{T}_{\mathrm{OC}}+\mathrm{CC}\right)$ and production period (milking period for milk production and composition ( $n=5$; fortnightly) as well as the first, second, and third months of lactation for FA $(\mathrm{n}=3$; once a month)) and their interaction according to the following model:

$$
Y_{i j k}=\mu+\alpha_{i}+\beta_{j}+\gamma_{i j}+\sigma_{i j k}+\varepsilon_{i j k}
$$

where $Y_{\mathrm{ijk}}$ : the dependent variable; $\mu$ : mean; $\alpha_{\mathrm{i}}$ : fix effect of the $\mathrm{i}^{\mathrm{th}}$ modality of the first factor (diet); $\beta_{\mathrm{j}}$ : fix effect of the $\mathrm{j}^{\text {th }}$ modality of the second factor (milking period); $\gamma_{\mathrm{ij}}$ : effect of the interaction between factors (diet $\times$ milking period); $\sigma_{\mathrm{ijk}}:$ random effect associated with the $\mathrm{k}$ observations (animal); $\varepsilon_{\mathrm{ijk}}$ : random residual effects associated with the k observations. 
Milk production and composition per lactation were performed using Analysis of Variance of one-factor (ANOVA 1; diet) according to the following model:

$$
\mathrm{Y}_{\mathrm{ij}}=\mu+\alpha_{\mathrm{i}}+\varepsilon_{\mathrm{ij}}
$$

where $Y_{\mathrm{ij}}$ : the dependent variable; $\mu$ : mean; $\alpha_{\mathrm{i}}$ : effect of $\mathrm{i}^{\text {th }}$ modality of diet; $\varepsilon_{\mathrm{ij}}$ : residual error.

For diet groups, effect significance was declared when $p<0.05$ and a tendency was stated at $0.05<p<0.10$. In the case of a significant effect, means were compared using the Tukey's test.

\section{Results}

\subsection{Milk Production and Physico-Chemical Composition}

Table 3 presents the daily production, composition, and acidity of milk. Milk composition was not affected by diet. However, the lactation period had a highly significant effect on all these parameters $(p<0.01)$. The interaction between diet and lactation period was significant only on ash content. Similar to milk composition, the daily production of milk and other compounds, and $\mathrm{NE}_{\text {milk }}$ were similar in all diet groups and significantly different by lactation period $(p<0.001)$ without a significant effect of diet and lactation period interaction. Also, $\mathrm{pH}$ and titratable acidity showed a similarity by diet groups and a very highly significant effect of the lactation period $(p<0.001)$. The diet and period interaction showed a tendency to have a significant effect on titratable acidity.

The yield per lactation of milk, fat, proteins, lactose, solids non-fat, total solids, and ash are presented in Table 4 . The parameters were not affected by the distributed diet, and they were similar in all groups.

\subsection{Milk Fatty Acids}

Table 5 reports the individual profiles, summaries, ratios, and indexes of FA in all groups according to feed diet. Butyric (C4:0), myristoleic (C14:1), pentadecanoic (C15:0), pentadecenoic C15:1, elaidic (9t-C18:1), oleic (C18:1n-9), trans-linoleic (6t-C18:2), $\alpha$-linolenic (C18:3n-3), $\gamma$-linolenic (C18:3n-6), arachidic (C20:0), heneicosanoic (C21:0), and docosahexaenoic (C22:6n-3; DHA) acids were affected significantly by the diet $(p<0.05)$. Lauric (C12:0), linoleic-cis (C18:2n-6), and eicosenoic acids (C20:1) tended to vary between diets $(p<0.1)$. The incorporation of $20 \%$ of OC reduced $9 \mathrm{t}-\mathrm{C} 18: 1$ and increased C18:1n-9 contents in milk fat compared to the control diet $(p<0.05)$. The introduction of $30 \%$ of CC in goat diet decreased C4:0, 9t-C18:1, 6t-C18:2and C20:0, and increased C15:0, C18:1n-9, C21:0 $(p<0.05)$. The TOC+CC milk fat contained lower proportions of C4:0, 9t-C18:1, 6t-C18:2, and C22:6n-3, and a higher proportion of C18:1n-9 than the control milk fat $(p<0.05)$. Most FA contents changed significantly during the lactation period $(p<0.05)$. The interaction between diet and lactation period had a significant effect on C14:1, C15:1, C18:0, 9t-C18:1, 6t-C18:2, C18:3n-3, erucic acid (C22:1n-9), and C22:6n-3 (DHA) $(p<0.05)$.

For FA summaries, SCFA, MCFA, and LCFA were similar in all groups. However, the diet affected MUFA, PUFA, and n-9 significantly $(p<0.05)$ (Table 5). Higher levels of MUFA and n-9 were observed with the incorporation of $20 \%$ of OC $(p<0.05)$ compared to the control group. The incorporation of OC and/or CC in the diet decreased PUFA proportion significantly in milk fat $(p<0.05)$. The FA summaries were stable during the lactation period except for SCFA and MCFA that changed significantly over time $(p<0.05)$. However, the DFA showed a tendency to decrease during the period $(p<0.1)$. The interaction between diet and period was without an effect on FA summaries. 
Table 3. Least squares means and standard error of the mean of daily production and composition, acidity and $\mathrm{NE}_{\text {milk }}$ of goat milk according to diet $(\mathrm{n}=220)$.

\begin{tabular}{|c|c|c|c|c|c|c|c|c|}
\hline Item & Co & $\mathbf{T}_{\mathrm{OC}}$ & $\mathrm{T}_{\mathrm{CC}}$ & $\mathrm{T}_{\mathrm{OC}+\mathrm{CC}}$ & SEM & Diet & $\begin{array}{l}p \text {-Value } \\
\text { Period }\end{array}$ & Diet $\times$ Period \\
\hline \multicolumn{9}{|l|}{ Chemical composition (\%) } \\
\hline Fat & 2.46 & 2.12 & 2.61 & 2.49 & 0.106 & 0.568 & $<0.001$ & 0.163 \\
\hline Proteins & 3.55 & 3.61 & 3.83 & 3.72 & 0.070 & 0.767 & $<0.001$ & 0.459 \\
\hline Lactose & 4.53 & 4.53 & 4.44 & 4.56 & 0.027 & 0.745 & $<0.001$ & 0.390 \\
\hline Solids non-fat & 9.14 & 9.05 & 9.24 & 9.30 & 0.075 & 0.839 & $<0.001$ & 0.541 \\
\hline Total Solids & 11.8 & 11.3 & 12.0 & 11.8 & 0.157 & 0.623 & $<0.001$ & 0.210 \\
\hline \multicolumn{9}{|l|}{ Daily production (g/day) } \\
\hline Milk & 415 & 362 & 325 & 403 & 11.5 & 0.311 & $<0.001$ & 0.178 \\
\hline Energy-corrected milk & 353 & 280 & 268 & 329 & 0.016 & 0.353 & $<0.001$ & 0.147 \\
\hline Fat corrected milk & 335 & 260 & 253 & 306 & 0.016 & 0.335 & $<0.001$ & 0.222 \\
\hline Fat & 7.15 & 5.11 & 5.66 & 5.88 & 0.369 & 0.593 & $<0.001$ & 0.392 \\
\hline Proteins & 10.1 & 9.09 & 8.71 & 9.92 & 0.372 & 0.685 & $<0.001$ & 0.173 \\
\hline Lactose & 13.6 & 12.2 & 11.0 & 13.2 & 0.541 & 0.481 & $<0.001$ & 0.129 \\
\hline Solids non-fat & 26.7 & 23.5 & 22.0 & 26.1 & 1.01 & 0.500 & $<0.001$ & 0.110 \\
\hline Total Solids & 34.0 & 26.7 & 27.2 & 32.0 & 1.27 & 0.381 & $<0.001$ & 0.077 \\
\hline $\begin{array}{c}\text { Net energy of milk }\left(\mathrm{NE}_{\text {milk }}\right) \\
(\mathrm{Mcal} / \mathrm{kg})\end{array}$ & 0.610 & 0.574 & 0.628 & 0.614 & 0.013 & 0.630 & $<0.001$ & 0.197 \\
\hline $\mathrm{pH}$ & 6.57 & 6.65 & 6.63 & 6.61 & 0.046 & 0.937 & $<0.001$ & 0.838 \\
\hline Acidity $\left({ }^{\circ} \mathrm{D}\right)$ & 15.9 & 15.7 & 15.7 & 15.3 & 0.224 & 0.823 & $<0.001$ & 0.061 \\
\hline
\end{tabular}

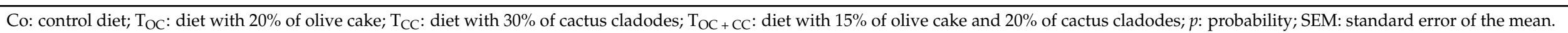


Table 4. Yield and composition per lactation of goat milk according to diet $(n=44)$.

\begin{tabular}{ccccccc}
\hline & Co & T $_{\text {OC }}$ & $\mathbf{T}_{\text {CC }}$ & $\mathbf{T}_{\text {OC }+ \text { CC }}$ & SEM & $p$-Value \\
\hline Yield & & & & & & \\
(kg/lactation) & & & & & & \\
Milk & 49.8 & 43.5 & 39.0 & 48.3 & 2.14 & 0.264 \\
Fat & 1.36 & 0.926 & 0.987 & 1.17 & 0.085 & 0.254 \\
Proteins & 1.76 & 1.54 & 1.42 & 1.76 & 0.069 & 0.228 \\
Lactose & 2.25 & 1.96 & 1.73 & 2.19 & 0.096 & 0.192 \\
Solids nonfat & 4.54 & 3.89 & 3.55 & 4.45 & 0.185 & 0.178 \\
Total Solids & 5.87 & 4.82 & 4.53 & 5.62 & 0.253 & 0.184 \\
Ash & 0.390 & 0.341 & 0.314 & 0.382 & 0.016 & 0.266 \\
\hline
\end{tabular}

Co: control diet; $\mathrm{T}_{\mathrm{OC}}$ : diet with $20 \%$ of olive cake; $\mathrm{T}_{\mathrm{CC}}$ : diet with $30 \%$ of cactus cladodes; $\mathrm{T}_{\mathrm{OC}}+\mathrm{CC}$ : diet with $15 \%$ of olive cake and $20 \%$ of cactus cladodes; $p$ : probability; SEM: standard error of the mean.

Table 5. Least square means and standard error of the mean of fatty acid profiles ( $\mathrm{g} / 100 \mathrm{~g}$ fat) and summaries ( $\mathrm{g} / 100 \mathrm{~g}$ fat), ratios, and indexes in goat milk fat according to diet $(n=132)$.

\begin{tabular}{|c|c|c|c|c|c|c|c|c|}
\hline \multicolumn{7}{|c|}{ Diet $^{1}$} & \multicolumn{2}{|c|}{$p$-Value } \\
\hline & Co & $\mathbf{T}_{\mathrm{OC}}$ & $\mathrm{T}_{\mathrm{CC}}$ & $\mathbf{T}_{\mathrm{OC}+\mathrm{CC}}$ & SEM & Diet & Period & $\begin{array}{l}\text { Diet } \times \\
\text { Period }\end{array}$ \\
\hline C4:0 & $0.286^{a}$ & $0.139^{a b}$ & $0.039^{b}$ & $0.081^{b}$ & 0.027 & 0.003 & 0.029 & 0.221 \\
\hline C6:0 & 0.798 & 0.755 & 0.769 & 0.790 & 0.046 & 0.995 & $<0.001$ & 0.221 \\
\hline C8:0 & 1.54 & 1.52 & 1.61 & 1.74 & 0.060 & 0.394 & 0.157 & 0.387 \\
\hline C10:0 & 5.39 & 5.41 & 5.48 & 5.13 & 0.142 & 0.586 & 0.495 & 0.707 \\
\hline C11:0 & 0.327 & 0.199 & 0.355 & 0.273 & 0.030 & 0.166 & 0.004 & 0.182 \\
\hline C12:0 & 2.48 & 2.71 & 2.90 & 2.43 & 0.075 & 0.074 & 0.104 & 0.748 \\
\hline C13:0 & 0.143 & 0.129 & 0.168 & 0.152 & 0.006 & 0.108 & 0.011 & 0.755 \\
\hline C14:0 & 7.05 & 6.85 & 7.74 & 6.89 & 0.161 & 0.112 & 0.021 & 0.958 \\
\hline C14:1 & $0.634^{\mathrm{ab}}$ & $0.685^{a b}$ & $0.523^{b}$ & $0.841^{a}$ & 0.034 & 0.001 & $<0.001$ & 0.001 \\
\hline C15:0 & $1.56^{\mathrm{b}}$ & $1.64^{\mathrm{ab}}$ & $1.82^{\mathrm{a}}$ & $1.63^{b}$ & 0.040 & 0.040 & $<0.001$ & 0.559 \\
\hline C15:1 & 0.440 & 0.477 & 0.365 & 0.506 & 0.017 & 0.008 & $<0.001$ & $<0.001$ \\
\hline C16:0 & 25.2 & 24.1 & 25.2 & 25.5 & 0.331 & 0.554 & $<0.001$ & 0.881 \\
\hline C16:1 & 1.15 & 1.11 & 1.13 & 1.15 & 0.039 & 0.987 & $<0.001$ & 0.554 \\
\hline C17:0 & 1.31 & 1.34 & 1.24 & 1.41 & 0.032 & 0.582 & 0.112 & 0.385 \\
\hline C17:1 & 0.460 & 0.447 & 0.454 & 0.517 & 0.013 & 0.302 & $<0.001$ & 0.936 \\
\hline C18:0 & 15.4 & 15.4 & 14.6 & 15.6 & 0.347 & 0.887 & $<0.001$ & 0.037 \\
\hline 9t-C18:1 & $1.95^{\mathrm{a}}$ & $1.32^{b}$ & $0.158^{c}$ & $0.101^{\mathrm{c}}$ & 0.114 & $<0.001$ & $<0.001$ & $<0.001$ \\
\hline C18:1n-9 & $24.7^{b}$ & $27.8^{a}$ & $26.8^{a}$ & $28.0^{a}$ & 0.464 & 0.015 & 0.997 & 0.476 \\
\hline 6t-C18:2 & $0.307^{\mathrm{a}}$ & $0.209^{a b}$ & $0.168^{b}$ & $0.152^{b}$ & 0.016 & 0.001 & $<0.001$ & 0.005 \\
\hline C18:2n-6 & 1.62 & 1.67 & 1.98 & 1.93 & 0.063 & 0.050 & 0.043 & 0.466 \\
\hline C18:3n-3 & $0.655^{\mathrm{a} b}$ & $0.695^{\mathrm{a}}$ & $0.483^{a b}$ & $0.425^{b}$ & 0.039 & 0.029 & 0.019 & 0.016 \\
\hline C18:3n-6 & $0.522^{a b}$ & $0.199^{b}$ & $0.454^{\mathrm{a}}$ & $0.091^{b}$ & 0.065 & 0.039 & 0.053 & 0.455 \\
\hline C20:0 & $0.849^{a}$ & $0.645^{a b}$ & $0.454^{b}$ & $0.841^{\mathrm{a}}$ & 0.050 & 0.014 & 0.743 & 0.100 \\
\hline C20:1 & 0.297 & 0.457 & 0.207 & 0.172 & 0.037 & 0.060 & 0.630 & 0.848 \\
\hline C20:2 & 0.317 & 0.258 & 0.296 & 0.122 & 0.037 & 0.285 & 0.781 & 0.882 \\
\hline C20:3n-3 & 0.256 & 0.129 & 0.197 & 0.122 & 0.028 & 0.386 & 0.188 & 0.869 \\
\hline C20:3n-6 & 0.225 & 0.288 & 0.227 & 0.172 & 0.024 & 0.566 & 0.707 & 0.357 \\
\hline C20:4n-6 & 0.327 & 0.228 & 0.227 & 0.213 & 0.042 & 0.754 & 0.063 & 0.891 \\
\hline C20:5n-3 & 0.317 & 0.338 & 0.345 & 0.243 & 0.035 & 0.648 & 0.294 & 0.985 \\
\hline
\end{tabular}


Table 5. Cont.

\begin{tabular}{|c|c|c|c|c|c|c|c|c|}
\hline & \multicolumn{4}{|c|}{$\operatorname{Diet}^{1}$} & \multirow[b]{2}{*}{ SEM } & \multirow[b]{2}{*}{ Diet } & \multicolumn{2}{|c|}{$p$-Value } \\
\hline & Co & $\mathrm{T}_{\mathrm{OC}}$ & $\mathrm{T}_{\mathrm{CC}}$ & $\mathrm{T}_{\mathrm{OC}}+\mathrm{CC}$ & & & Period & $\begin{array}{l}\text { Diet } \times \\
\text { Period }\end{array}$ \\
\hline C21:0 & $0.736^{b}$ & $0.705^{b}$ & $1.23^{\mathrm{a}}$ & $1.06^{\mathrm{ab}}$ & 0.060 & 0.003 & 0.227 & 0.099 \\
\hline C22:0 & 0.470 & 0.338 & 0.720 & 0.415 & 0.098 & 0.537 & 0.518 & 0.696 \\
\hline C22:1n-9 & 0.399 & 0.377 & 0.197 & 0.182 & 0.058 & 0.454 & 0.048 & 0.039 \\
\hline C22:2 & 0.348 & 0.298 & 0.158 & 0.142 & 0.031 & 0.087 & 0.019 & 0.237 \\
\hline$C 22: 6 n-3$ & $0.378^{a}$ & $0.278^{a b}$ & $0.296^{\mathrm{a}}$ & $0.172^{b}$ & 0.023 & 0.014 & 0.168 & 0.024 \\
\hline C23:0 & 0.501 & 0.338 & 0.552 & 0.334 & 0.053 & 0.269 & 0.280 & 0.583 \\
\hline C24:0 & 0.389 & 0.228 & 0.355 & 0.273 & 0.051 & 0.678 & 0.177 & 0.658 \\
\hline C24:1 & 0.256 & 0.348 & 0.138 & 0.192 & 0.032 & 0.110 & 0.878 & 0.303 \\
\hline \multicolumn{9}{|l|}{ Summary $^{2}$} \\
\hline SCFA & 8.02 & 7.83 & 7.90 & 7.75 & 0.211 & 0.987 & 0.048 & 0.585 \\
\hline MCFA & 10.6 & 10.6 & 11.7 & 10.6 & 0.238 & 0.593 & 0.003 & 0.931 \\
\hline LCFA & 81.4 & 81.6 & 80.4 & 81.7 & 0.375 & 0.891 & 0.104 & 0.666 \\
\hline SFA & 64.5 & 62.4 & 65.2 & 64.6 & 0.420 & 0.319 & 0.114 & 0.433 \\
\hline MUFA & $30.3^{b}$ & $33.0^{\mathrm{a}}$ & $29.9^{b}$ & $31.6^{\mathrm{ab}}$ & 0.374 & 0.005 & 0.623 & 0.662 \\
\hline PUFA & $5.27^{\mathrm{a}}$ & $4.59^{b}$ & $4.83^{b}$ & $3.79^{b}$ & 0.270 & 0.014 & 0.333 & 0.904 \\
\hline DFA & 50.9 & 53.0 & 49.3 & 51.0 & 0.459 & 0.107 & 0.062 & 0.631 \\
\hline$n-3$ & 1.61 & 1.44 & 1.32 & 0.962 & 0.092 & 0.125 & 0.107 & 0.298 \\
\hline$n-6$ & 3.00 & 2.59 & 3.06 & 2.56 & 0.111 & 0.153 & 0.174 & 0.116 \\
\hline $\mathrm{n}-9$ & $27.0^{\mathrm{b}}$ & $29.5^{a}$ & $27.1^{a b}$ & $28.3^{\mathrm{ab}}$ & 0.398 & 0.044 & 0.752 & 0.455 \\
\hline \multicolumn{9}{|l|}{ Ratio } \\
\hline$n-6 / n-3$ & $1.87^{a b}$ & $1.80^{\mathrm{b}}$ & $2.31^{\mathrm{a}}$ & $2.66^{\mathrm{a}}$ & 0.080 & 0.046 & 0.055 & 0.062 \\
\hline UFA/SFA & $0.551^{\mathrm{a} b}$ & $0.602^{\mathrm{a}}$ & $0.533^{b}$ & $0.549^{a} b$ & 0.010 & 0.036 & 0.144 & 0.778 \\
\hline PUFA/SFA & 0.082 & 0.090 & 0.070 & 0.060 & 0.007 & 0.112 & 0.162 & 0.841 \\
\hline $\begin{array}{l}\text { MUFA/PUFA } \\
\text { Index }{ }^{3}\end{array}$ & $5.75^{b}$ & $7.19^{a b}$ & $6.19^{b}$ & $8.35^{\mathrm{a}}$ & 0.264 & 0.009 & 0.978 & 0.325 \\
\hline $\mathrm{AI}$ & 1.57 & 1.44 & 1.70 & 1.57 & 0.041 & 0.468 & 0.023 & 0.953 \\
\hline $\mathrm{TI}$ & $2.17^{\mathrm{b}}$ & $2.04^{b}$ & $2.27^{a b}$ & $2.36^{\mathrm{a}}$ & 0.040 & 0.002 & 0.014 & 0.012 \\
\hline $\begin{array}{c}(\mathrm{C} 18: 0+\mathrm{C} 18: 1) \\
/ \mathrm{C} 16: 0\end{array}$ & 1.67 & 1.85 & 1.64 & 1.71 & 0.033 & 0.455 & $<0.001$ & 0.678 \\
\hline$\Delta 9 C 14$ & $0.083^{a b}$ & $0.091^{\mathrm{a}}$ & $0.063^{\mathrm{b}}$ & $0.109^{a}$ & 0.004 & $<0.001$ & $<0.001$ & 0.001 \\
\hline$\Delta 9 \mathrm{C} 16$ & 0.043 & 0.044 & 0.043 & 0.043 & 0.001 & 0.754 & $<0.001$ & 0.536 \\
\hline$\Delta 9 \mathrm{C} 18$ & 0.634 & 0.654 & 0.649 & 0.643 & 0.005 & 0.531 & $<0.001$ & 0.001 \\
\hline
\end{tabular}

${ }^{1}$ Co: control diet; $\mathrm{T}_{\mathrm{OC}}$ : diet with $20 \%$ of olive cake; $\mathrm{T}_{\mathrm{CC}}$ : diet with $30 \%$ of cactus cladodes; $\mathrm{T}_{\mathrm{OC}}+\mathrm{CC}$ : diet with $15 \%$ of olive cake and $20 \%$ of cactus cladodes; ${ }^{2}$ DFA: desirable fatty acids; LCFA: long-chain fatty acids; MCFA: medium-chain fatty acids; MUFA: mono-unsaturated fatty acids; PUFA: poly-unsaturated fatty acids; SCFA: short-chain fatty acids; SFA: saturated fatty acids; UFA: unsaturated fatty acids; ${ }^{3}$ AI: Atherogenicity index; TI: Thrombogenic index; $\Delta 9 \mathrm{C} 14=(\mathrm{C} 14: 1) /(\mathrm{C} 14: 1+\mathrm{C} 14: 0)$ activity of $\Delta 9$ desaturase enzyme to convert C14:0 into $\mathrm{C} 14: 1 \mathrm{n} 9 ; \Delta 9 \mathrm{C} 16=(\mathrm{C} 16: 1) /(\mathrm{C} 16: 1+\mathrm{C} 16: 0)$ activity of $\Delta 9$ desaturase enzyme to convert $\mathrm{C} 16: 0$ into $\mathrm{C} 16: 1 \mathrm{n} 9 ; \Delta 9 \mathrm{C} 18=(\mathrm{C} 18: 1) /(\mathrm{C} 18: 1+\mathrm{C} 18: 0)$ activity of $\Delta 9$ desaturase enzyme to convert C18:0 into C18:1n9; $p$ : probability; SEM: standard error of the mean; a,b,c: Values followed by different letters differ statistically by Tukey's test at $p<0.05$.

For FA ratios, the diet had a significant effect on n-6/n-3, UFA/SFA, and MUFA/PUFA (Table 4). The n-6/n-3 ratio was higher in milk from the two groups supplemented with CC than in one from the OC group, but all test groups were similar to the control group. Also, $\mathrm{T}_{\mathrm{OC}}+\mathrm{CC}$ group produced milk fat with a MUFA/PUFA significantly higher than that from the control group $(p<0.01)$. The lactation period and the interaction of the two studied factors did not affect FA ratios, but $n-6 / n-3$ showed a tendency to be affected by these factors $(p<0.1)$.

Concerning FA indexes, TI and $\triangle 9 \mathrm{C} 14$ were variable between diet groups $(p<0.01)$. The introduction of both OC and CC in the diet increased TI of milk significantly compared to the milk from the control group. Despite that $\triangle 9 \mathrm{C} 14$ was affected by diet; its contents in the control were similar to test groups. All the studied indexes were significantly variables 
by period $(p<0.05)$. The effect of the interaction diet and period was significant in TI, $\Delta 9 \mathrm{C} 14$, and $\Delta 9 \mathrm{C} 18(p<0.05)$.

\section{Discussion}

\subsection{Milk Production and Physico-Chemical Composition}

In all the goat groups, daily and total milk yields were low compared to other dairy goat breeds. According to Hilal [37], Beni Arouss is an indigenous breed with a milk production varying between 40 and $54 \mathrm{~kg} /$ lactation, similar to the current results. In the present experiment, goats valorized well OC and CC as feed since there was no diet effect on milk production. Many studies in the literature reported the absence of diet effect on goat daily milk production similarl to the present results [38]. Indeed, many authors [22-24,39,40] already reported the absence of OC effect as block, silage, dried and partially stoned in the diet of cows, ewes, or dairy goats. The lack of CC effect on goat milk production is in agreement with observations of Ichimura et al. [20] with 20\%, and Atti et al. [25] and Mahouachi et al. [27] with ad libitum spineless varieties of cactus.

Fat content affects cheese yield, and the firmness, color, and flavor of dairy products [41]. Many factors as breed, lactation period, and feed influence milk fat. In the present experiment, milk fat content was lower than the species average (4.25\%), as reported by Kumar et al. [19]. However, similar values were reported for the Japanese Saanen goats by Ichimura et al. [20] as the indigenous breed potential. These low values could be explained by the potential of the indigenous breed. Protein, lactose, solids non-fat, and ash contents were similar to the milk goat average with $3.52,4.27,8.75$, and $0.86 \%$, respectively, as reported by Kumar et al. [19]. Total solid content is an important parameter because it reflects dairy product yield [42]. The total solid results were in the line of the values reported for goats' standard [19] and similar to these reported for Saanen goats receiving $49 \%$ of CC [40]. Vargas-Bello-Pérez et al. [40] reported a lack of $25 \%$ dried and partly stoned OC effect on ewe milk ash with $0.9 \%$ similarly to the current results. The OC supplementation did not affect milk compound contents and yields, as already reported by many authors $[9,24,39,43,44]$. Also, CC incorporation had no-effect on protein, and fat contents in agreement with Atti et al. [25] and Mahouachi et al. [27] with ad libitum spineless CC, and on lactose content in concordance with Mouhaddach et al. [45] with 50\% of CC silage in Sardi ewes' diet. The absence of diet effects on milk chemical composition could be due to the lack of effects of long-chain unsaturated FA (that are higher in by-products, especially OC) and NDF (that are slightly different) of diets on ruminal bacterial activity [44].

The variability of milk chemical composition during the lactation period is linked to the "dilution effect" because milk production is negatively correlated with milk composition as fat and protein [46].

ECM and FCM were similar in all groups because of the no effect of diet on physicochemical parameters. Contrary to the current results, Abbeddou et al. [47] found a decrease of ECM yield of Awassi ewes supplemented with $30 \%$ OC administration by contrast to the present results because of their low contents on fat and protein in milk resulted from the low energy and the high offered quantities, compared to control diet. Similar to the current found, Hadjipanayiotou [22] reported no effect of barley hay substitution by crude OC silage on FCM of Damascus goat. The net energy provided by $1 \mathrm{~kg}$ of milk obtained with our indigenous goats, fed with conventional concentrate and alternatives feed resources, was similar to the standard energy provided by dairy goat milk $(0.58 \mathrm{Mcal} / \mathrm{Kg})[48]$.

The observed milk $\mathrm{pH}$ values were in the range of the goat species standard (6.4-6.9) [19]. Similarly, to the current results, the incorporation of $15-20 \%$ of OC did not affect the $\mathrm{pH}$ of milk of ewes and buffaloes, which ranged from 6.6 to $6.8[39,44]$. Costa et al. [26] found no effect of $25-100 \%$ CC on milk titratable acidity, which presents the lactic acid production, in agreement with the present results. 


\subsection{Milk Fatty Acids}

\subsubsection{Individual Fatty Acids}

The fat composition of goat milk is an important parameter affecting the technological, organoleptic, and dietetic quality of dairy products [41]. Goat milk FA are the main drivers of milk flavor or rancidity [49]. Generally, the FA in the ruminant milk are provided directly from the diet, from the mammary gland by the de novo synthesis, and ruminal bacteria production. In the present experiment, FA of milk fat presented high contents of oleic (C18:1n-9), palmitic (C16:0), stearic (C18:0), myristic (C14:0), capric (C10:0), and lauric (C12:0) acids in order of importance, that is in agreement with the observations of MolinaAlcaide et al. [9] for Granadina goat milk. Milk FA proportion depends mainly on diet, breed, and stage of lactation [50] what explain the variability of these parameters during the lactation period.

The administration of $\mathrm{CC}$ in goat diet $\left(\mathrm{T}_{\mathrm{CC}}\right.$ and $\left.\mathrm{T}_{\mathrm{OC}}+\mathrm{CC}\right)$ decreased C4:0 levels, contrary to Costa et al. [26], who reported a lack of changes in C4:0 milk with $25-100 \%$ CC as a feed. This discordance could be due to the variation of CC composition according to the varieties [42]. The FA with less than 16 carbons come from de novo synthesis [51]. The low content of C4:0 could be explained by the fact that CC is rich in non-structural carbohydrates as small fiber particles, which increases propionate formation and implicitly, decreases acetate production, the main element for de novo synthesis [38]. The excess of C4:0 in milk increases rancidity [49] therefore, it is expected a better shelf-life for CC milk.

The greater C15:0 proportion in $\mathrm{T}_{\mathrm{CC}}$ milk fat was similar to Costa et al. [26] with $75-100 \%$ of CC, and that could be explained by the high content of CC in nonstructural carbohydrates that induces a high propionate production, which promotes the odd-chain FA synthesis [52].

The supplementation with OC and CC increased C18:1n-9 content. This FA is considered as beneficial in human nutrition at several levels because it is known for its capacity to inhibit cancer-cells cycle, to prevent leukemia and apoptosis [53], and cardiac diseases and notably to reduce low-density lipoprotein cholesterol (LDL) [54]. Generally, the FA with more than 18 carbons are provided from diet or body reserves mobilization [51]. Generally, the $\mathrm{C} 18: 1 \mathrm{n}-9$ is derived from the diet and the mammary $\Delta 9$-desaturase enzyme action, also named stearoyl-coenzyme A desaturase, on C18:0 [55]. The role of $\Delta 9$-desaturase enzyme is to convert SFA to MUFA by inserting a double bond at the 9th carbon atom of the FA chain. The increase of C18:1n-9 level was observed as well by Terramoccia et al. [39], Vargas-Bello-Pérez et al. [40], and Chiofalo et al. [44] with $15-25 \%$ of OC in buffalo and ewe milk fat. The high proportion of C18:1n-9 in OC milk comes directly from diet to be directly incorporated in the milk because the $\Delta 9$-desaturase activity on C18 FA $(\triangle 9 \mathrm{C} 18)$ was similar in milk fat of all groups. Sanz Sampelayo et al. [56] reported that goat fed lipid supplements rich with PUFA had higher C18:1 and C18:0 levels as a result of biohydrogenation that takes place in the rumen, and its major substrates are PUFA with 18 carbon atoms. Due to the microbial lipolysis action, especially Butyrivibrio fibrisolves, the biohydrogenation results in SFA production. The OC is known for its high content on C18:1n-9 (60.4-75.8 g/100 g fat) [40,57-59]. In addition to the high level on this acid from the residual olive oil, OC contains a high content of fibers and phenols that increases transit speed and could inactivate some responsible microorganisms of the biohydrogenation in the rumen (especially Butyrivibrio fibrisolves) and consequently, they are responsible for the lack of biohydrogenation of C18:1 to saturated form C18:0 $[9,44]$ increasing thus a direct transfer of this FA from feed to milk.

Contrary to the current results, Costa et al. [26] reported no effect of $25 \%$ CC on C18:1n-9. The presence of C18:1n-9 high level in milk fat could be coming from CC that contains $8.5-36.3 \%$ of total FA of C18:1 according to the cultivars and the cladodes' age (young or old) [60,61], that could be escaped from rumen biohydrogenation.

Unlike C18:1n-9c, 9t-C18:1 and trans unsaturated FA increase the risk of coronary diseases $[62,63]$. The $9 \mathrm{t}-\mathrm{C} 18: 1$ in dairy products is a result of incomplete biohydrogenation of PUFA C18:3n-3 in the rumen. The lower content of 9t-C18:1 and 6t-C18:2 in milk fat 
from $\mathrm{T}_{\mathrm{CC}}$ and $\mathrm{T}_{\mathrm{OC}}+\mathrm{CC}$ goats could be explained by higher phenol contents in these diets that could preserve these dietary PUFA from ruminal hydrogenation, which leads to low FA trans in milk fat.

The C20:0 decreased by 30\% CC in $\mathrm{T}_{\mathrm{CC}}$ milk fat, contrary to Costa et al. [26]. That result could be due to the elongation of $\mathrm{C} 20: 0$ to $\mathrm{C} 21: 0$, which increased in $\mathrm{T}_{\mathrm{CC}}$ milk fat. The DHA, that is an n-3 FA derived from C18:3n-3, is essential for the human diet because of its effects anti-atherogenic and on development and optimal functioning of the nervous system [64]. The mixing of $\mathrm{OC}$ and $\mathrm{CC}$ in the goat diet had a negative effect by reducing the C22:6n-3 DHA in milk fat compared to the control.

\subsubsection{Fatty Acids Summaries}

The summaries of FA chains (SCFA, MCFA, and LCFA) were similar despite that milk fat of test groups had variable content of FA with long-chain compared to the control diet. The similarity of SCFA suggests that there was no difference in the organoleptic properties of produced milk [23].

The general profile of goat milk fat had high SFA and low PUFA contents, as reported by Vasta and Luciano [10] for ruminant products. The PUFA, MUFA, and SFA results were in the range reported by Markiewicz-Kęszycka et al. [50] with 3-4\%, 20-35\%, and $60-70 \%$, respectively.

The administration of OC did not change SFA proportion, similar to Terramoccia et al. [39] with 15\% OC in buffalo milk fat. Abbeddou et al. [47], Chiofalo et al. [44], Keles et al. [24], and Vargas-Bello-Pérez et al. [40] reported an increase of ewe and goat milk MUFA by $10-30 \%$ $\mathrm{OC}$, which is in concordance with the current result. This increase results from the high content of C18:1n-9 in OC milk fat that is reflected in the higher level of n-9. The PUFA in milk fat of OC were lower than in the control group because of the increase of MUFA in this milk. The similarity of OC milk FA to control, except for C18:1n-9, could be the responsible of the lack of effect on DFA, n-3 and n-6. Chiofalo et al. [44], and Terramoccia et al. [39] also reported no effect of OC on $n-3$ and n-6, similar to the present results.

Costa et al. [26] observed no effect of 25\% CC in the diet on SFA, MUFA, DFA, n-3, and n-6 comparatively to the current found. The PUFA of CC milk were lower than control because of its low content of 6t-C18:2n and the decrease tendency of C22:2 levels.

\subsubsection{Fatty Acids Ratios}

The $n-6 / n-3$ ratio expresses heart diseases and cancer risk that could present food and this ratio should be lower to 4 to be healthy [65]. This ratio was less than 2.41 in goat milk, which means it is beneficial in human nutrition. Terramoccia et al. [39], with 15\% dried stoned OC in buffalo milk, reported a lack of effect on this ratio similar to the current one found.

The PUFA/SFA ratio, which presents a factor of cardiovascular disease risk, was 0.08 in goat milk fat, which is lower than the recommendation that should be high and at least 0.45 [66]. Lovegrove [67] reported that the substitution of SFA with PUFA decreases cardiovascular disease events risk by $27 \%$. The MUFA/PUFA was higher in the $\mathrm{T}_{\mathrm{OC}}+\mathrm{CC}$ milk because this milk contained the lowest percentage of PUFA among all groups.

\subsubsection{Fatty Acids Indexes}

The AI and TI are two indicators of cardiovascular disease, taking into account the negative effect of C12:0, C14:0, and C16:0, and allowing for a comparison between foods as suggested by Ulbricht and Southgate [35]. The observed AI was slightly lower than milk, butter, and cheese (2.03), and TI was similar to the same products (2.07), according to the same authors. The TI of Toc + cc milk was higher because this index is based on MUFA and PUFA that were variable compared to control as MUFA/PUFA ratio. The observed AI was slightly lower, and TI was similar to values reported by Arco-Pérez et al. [23] in goat milk with $20 \%$ OC silage (AI: 1.92-2.17; TI: 1.96-2.19); they found the absence of OC effect on these indexes similarly to our results. The obtained values of $(\mathrm{C} 18: 0+\mathrm{C} 18: 1) / \mathrm{C} 16: 0$ 
that indicates the lipid effect on health, were similar to those obtained for goat and beef longissimus dorsi muscle as observed by Banskalieva et al. [34].

The $\Delta 9 C 14, \Delta 9 C 16$, and $\Delta 9 C 18$ are indicators describing the activity of $\Delta 9$ desaturase enzyme to convert C14:0 into C14:1n9, C16:0 into C16:1n9, and C18:0 FA into C18:1n9 in the mammary cells [68,69]. Arco-Pérez et al. [23] reported a lack of $20 \%$ OC silage effects on $\Delta 9 \mathrm{c} 14, \Delta 9 \mathrm{c} 16$ in goat milk similarly to the current result, but they reported a $\Delta 9 \mathrm{C} 18$ decrease contrarily to the present found. The similarity of $\Delta 9 \mathrm{c} 18$ inter-groups allows concluding that the high content of $\mathrm{C} 18: 1 \mathrm{n}-9$ in test milk fat is provided from the diet.

\section{Conclusions}

The study demonstrated that olive cake and cactus cladodes could be administrated in the lactating goat diet with rates that could reach $20 \%$ and $30 \%$ of the concentrate diet, respectively. Their introduction as feed did not affect milk production performance. Also, the physico-chemical composition of goat milk obtained with a diet containing olive cake and/or cactus cladodes was similar to a conventional feed composed of barley grain and fava beans used by farmers. The quality of milk varied slightly according to the incorporation of these resources as a feed. The olive cake and cactus cladodes improved the individual fatty acids of milk by increasing oleic acid and decreasing elaidic acid. However, the use simultaneously the two resources in the diet reduced the level of DHA negatively. Nevertheless, their incorporation reduced the PUFA in milk fat without affecting the PUFA to SFA ratio. Thereby, olive cake and cactus cladodes are two alternative feed resources that could be introduced in the diet of lactating goats to reduce feeding costs. Further studies are recommended to deepen the knowledge on the effect of olive cake and cactus cladodes on ruminal microbiota and different goat milk product characteristics.

Author Contributions: Conceptualization, S.E.O.; methodology, S.E.O., M.C., J.-L.H., J.-F.C.; laboratory analysis, S.E.O.; formal analysis, S.E.O., M.C., J.-L.H., J.-F.C.; data curation, S.E.O.; writingoriginal draft preparation, S.E.O., Y.C.; writing-review and editing, Y.C., M.C., J.-L.H., J.-F.C.; project administration, S.E.O., J.-F.C.; funding acquisition, S.E.O. All authors have read and agreed to the published version of the manuscript.

Funding: This study was supported by the Academy for Research and Higher Education-Development Cooperation Committee (ARES-CCD), Brussels, Belgium. It was carried out as part of the Research for Development Project (2013-2018).

Institutional Review Board Statement: The study was conducted according to the guidelines of the Declaration of Helsinki, and approved by the Ethics Committee of the Regional Center of Agricultural Research (CRRA of Tangier; Morocco) (protocol code 02/CRRA/2017).

Informed Consent Statement: Informed consent was obtained from all subjects involved in the study.

Data Availability Statement: The data that support the findings of this study are available upon request from the authors.

Acknowledgments: The authors would like to thank the Research for Development Project collaborators. Also, the authors acknowledge the technical assistance of the staff at the Experiment Station of INRA-Tangier.

Conflicts of Interest: The authors declare no conflict of interest.

\section{References}

1. Chebli, Y.; El Otmani, S.; Chentouf, M.; Hornick, J.L.; Bindelle, J.; Cabaraux, J.-F. Foraging behavior of goats browsing in Southern Mediterranean forest rangeland. Animals 2020, 10, 196. [CrossRef] [PubMed]

2. Chebli, Y.; El Otmani, S.; Hornick, J.L.; Cabaraux, J.F.; Chentouf, M. Pastoral production and use of forest rangelands in Western Rif. Afr. Med. Agric. J. Al Awamia 2020, 128, 1-16.

3. López, M.C.; Estellés, F.; Moya, V.J.; Fernández, C. Use of dry citrus pulp or soybean hulls as a replacement for corn grain in energy and nitrogen partitioning, methane emissions, and milk performance in lactating Murciano-Granadina goats. J. Dairy Sci. 2014, 97, 7821-7832. [CrossRef] [PubMed]

4. Cappai, M.G.; Liesegang, A.; Dimauro, C.; Mossa, F.; Pinna, W. Circulating electrolytes in the bloodstream of transition Sarda goats make the difference in body fluid distribution between single vs. twin gestation. Res. Vet. Sci. 2019, 123, 84-90. [CrossRef] [PubMed] 
5. Alary, V.; Nefzaoui, A.; Ben Jemaa, M. Promoting the adoption of natural resource management technology in arid and semi-arid areas: Modelling the impact of spineless cactus in alley cropping in Central Tunisia. Agric. Syst. 2007, 94, 573-585. [CrossRef]

6. Chebli, Y.; Chentouf, M.; Mrabet, R.; Keli, A. Production et utilisation des parcours dans les montagnes rifaines du Nord du Maroc. Opt. Méditerr. 2014, 108, 109-113.

7. Chebli, Y.; Chentouf, M.; Hornick, J.L.; Cabaraux, J.F. Extensive goat production systems in northern Morocco: Production and use of pastoral resources. In Grassland Resources for Extensive Farming Systems in Marginal Lands: Major Drivers and Future Scenarios, Proceeding of the 19th Symposium of the European Grassland Federation, Alghero, Italy, 7-10 May 2017; Porqueddu, A., Franca, C., Lombardi, A., Molle, G., Peratoner, G., Hopkins, G., Eds.; Organising Committee of the 19th Symposium of the European Grassland Federation: Sassari, Italy, 2017; pp. 131-133.

8. Chebli, Y.; Chentouf, M.; Ozer, P.; Hornick, J.L.; Cabaraux, J.F. Forest and silvopastoral cover changes and its drivers in northern Morocco. Appl. Geogr. 2018, 101, 23-35. [CrossRef]

9. Molina-Alcaide, E.; Morales-García, E.Y.; Martín-García, I.; Ben Salem, H.; Nefzaoui, A.; Sanz-Sampelayo, M.R. Effects of partial replacement of concentrate with feed blocks on nutrient utilization, microbial $\mathrm{N}$ flow, and milk yield and composition in goats. J. Dairy Sci. 2010, 93, 2076-2087. [CrossRef]

10. Vasta, V.; Luciano, G. The effects of dietary consumption of plants secondary compounds on small ruminants' products quality. Small Rumin. Res. 2011, 101, 150-159. [CrossRef]

11. Molina-Alcaide, E.; Yáñez-Ruiz, D.R. Potential use of olive by-products in ruminant feeding: A review. Anim. Feed Sci. Technol. 2008, 147, 247-264. [CrossRef]

12. Vasta, V.; Nudda, A.; Cannas, A.; Lanza, M.; Priolo, A. Alternative feed resources and their effects on the quality of meat and milk from small ruminants. Anim. Feed Sci. Technol. 2008, 147, 223-246. [CrossRef]

13. Dermeche, S.; Nadour, M.; Larroche, C.; Moulti-Mati, F.; Michaud, P. Olive mill wastes: Biochemical characterizations and valorization strategies. Process. Biochem. 2013, 48, 1532-1552. [CrossRef]

14. El Otmani, S.; Chentouf, M.; Hornick, J.L.; Cabaraux, J.F. Chemical composition and in vitro digestibility of alternative feed resources for ruminants in Mediterranean climates: Olive cake and cactus cladodes. J. Agric. Sci. 2019, 157, 260-271. [CrossRef]

15. Ben Salem, H.; Nefzaoui, A.; Ben Salem, L. Spineless cactus (Opuntia ficus indica f. inermis) and oldman saltbush (Atriplex nummularia L.) as alternative supplements for growing Barbarine lambs given straw-based diets. Small Rumin. Res. 2004, 51, 65-73. [CrossRef]

16. Gusha, J.; Halimani, T.E.; Katsande, S.; Zvinorova, P.I. Performance of goats fed on low quality veld hay supplemented with fresh spiny cactus (Opuntia megacantha) mixed with browse legumes hay in Zimbabwe. Trop. Anim. Health Prod. 2014, 46, 1257-1263 [CrossRef] [PubMed]

17. de Rancourt, M.; Fois, N.; Lavin, M.P.; Tchakérian, E.; Vallerand, F. Mediterranean sheep and goats production: An uncertain future. Small Rumin. Res. 2006, 62, 167-179. [CrossRef]

18. Haenlein, G.F.W. Past, present, and future perspectives of small ruminant dairy research. J. Dairy Sci. 2001, 84, 2097-2115. [CrossRef]

19. Kumar, S.; Kumar, B.; Kumar, R.; Kumar, S. Nutritional features of goat milk-A Review. Indian J. Dairy Sci. 2012, 65, $266-273$.

20. Ichimura, H.; Ishikawa, S.; Isobe, N.; Hayashi, Y. Effects of spineless cactus feeding on milk production, milk quality and antioxidant capacity in dairy goat. In Proceedings of the 5th International Conference on Sustainable Animal Agriculture for Developing Countries, Bangkok, Thailand, 27-30 October 2015; pp. 309-315.

21. Nudda, A.; Buffa, G.; Atzori, A.S.; Cappai, M.G.; Caboni, P.; Fais, G.; Pulina, G. Small amounts of agro-industrial byproducts in dairy ewes diets affects milk production traits and hematological parameters. Anim. Feed Sci. Technol. 2019, 251, 76-85. [CrossRef]

22. Hadjipanayiotou, M. Feeding ensiled crude olive cake to lactating Chios ewes, Damascus goats and Friesian cows. Livest. Prod. Sci. 1999, 59, 61-66. [CrossRef]

23. Arco-Pérez, A.; Ramos-Morales, E.; Yáñez-Ruiz, D.R.; Abecia, L.; Martín-García, A.I. Nutritive evaluation and milk quality of including of tomato or olive by-products silages with sunflower oil in the diet of dairy goats. Anim. Feed Sci. Technol. 2017, 232, 57-70. [CrossRef]

24. Keles, G.; Yildiz-Akgul, F.; Kocaman, V. Performance and milk composition of dairy goats as affected by the dietary level of stoned olive cake silages. Asian Australas. J. Anim. Sci. 2017, 30, 363-369. [CrossRef] [PubMed]

25. Atti, N.; Maamouri, O.; Hajji, H.; Mahouachi, M. Utilisation du cactus inerme comme aliment de base pour la chèvre en lactation: Impacts sur la production laitière et la croissance des chevreaux. Livest. Res. Rural Dev. 2010, 22, 1-10.

26. Costa, R.G.; Filho, E.M.B.; Queiroga, R.C.R.E.; Madruga, M.S.; de Medeiros, A.N.; de Oliveira, C.J.B. Chemical composition of milk from goats fed with cactus pear (Opuntia ficus-indica L. Miller) in substitution to corn meal. Small Rumin. Res. 2010, 94, 214-217. [CrossRef]

27. Mahouachi, M.; Atti, N.; Hajji, H. Use of spineless cactus (Opuntia ficus indica f. inermis) for dairy goats and growing kids: Impacts on milk production, kid's growth, and meat quality. Sci. World J. 2012, 2012, 321567. [CrossRef] [PubMed]

28. Ruiz, R.; Oregui, L.M.; Herrero, M. Comparison of models for describing the lactation curve of Latxa sheep and an analysis of factors affecting milk yield. J. Dairy Sci. 2000, 83, 2709-2719. [CrossRef]

29. NRC. Nutrient Requirements of Small Ruminants; National Academies Press: Washington, DC, USA, 2007.

30. ALP (Agroscope Liebefeld-Posieux). Feeding Recommendations and Nutrient Tables; Swiss Bee Research Centre: Berne, Switzerland, 2008.

31. NRC. Nutrient Requirements of Dairy Cattle; National Academies Press: Washington, DC, USA, 2001.

32. Almeida, S.G.; Dórea, J.G. Quality control of banked milk in Brasília, Brazil. J. Hum. Lact. 2006, 22, 335-339. [CrossRef] 
33. Barbano, D.M.; Clark, J.L.; Dunham, C.E. Comparison of Babcock and ether extraction methods for determination of fat content of milk: Collaborative study. AOAC 1988, 71, 898-914. [CrossRef]

34. AOAC (Association of Official Analytical Chemists). Official Methods of Analysis, 15th ed.; AOAC International: Arlington, VA, USA, 1990.

35. Banskalieva, V.; Sahlu, T.; Goetsch, A.L. Fatty acid composition of goat muscles and fat depots: A review. Small Rumin. Res. 2000, 37, 255-268. [CrossRef]

36. Ulbricht, T.L.V.; Southgate, D.A.T. Coronary heart disease: Seven dietary factors. Lancet 1991, 338, 985-992. [CrossRef]

37. Hilal, B. Caractérisation Phénotypique, Génétique Moléculaire et Zootechnique de la Population Caprine Hamra Dans Deux Régions Différentes (Béni Arouss et Rommani). Ph.D. Thesis, Agricultural and Agri-food sciences, Agronomic and Veterinary Institute Hassan II, Rabat, Morocco, 19 April 2018.

38. Cordova-Torres, A.V.; Costa, R.G.; Araújo Filho, J.T.; Medeiros, A.N.; Andrade-Montemayor, H.M. Meat and milk quality of sheep and goat fed with cactus pear. J. Prof. Assoc. Cactus Dev. 2017, 19, 11-31.

39. Terramoccia, S.; Bartocci, S.; Taticchi, A.; Di Giovanni, S.; Pauselli, M. Use of dried stoned olive pomace in the feeding of lactating buffaloes: Effect on the quantity and quality of the milk produced. Asian Australas. J. Anim. Sci. 2013, 26, 971-980. [CrossRef] [PubMed]

40. Vargas-Bello-Pérez, E.; Vera, R.R.; Aguilar, C.; Lira, R.; Peña, I.; Fernández, J. Feeding olive cake to ewes improves fatty acid profile of milk and cheese. Anim. Feed Sci. Technol. 2013, 184, 94-99. [CrossRef]

41. Chilliard, Y.; Ferlay, A.; Rouel, J.; Lamberet, G. A review of nutritional and physiological factors affecting goat milk lipid synthesis and lipolysis. J. Dairy Sci. 2003, 8, 1751-1770. [CrossRef]

42. Catunda, K.L.M.; de Aguiar, E.M.; de Góes Neto, P.E.; da Silva, J.G.M.; Moreira, J.A.; do Nascimento Rangel, A.H.; de Lima Júnior, D.M. Gross composition, fatty acid profile and sensory characteristics of Saanen goat milk fed with Cacti varieties. Trop. Anim. Health Prod. 2016, 48, 1253-1259. [CrossRef]

43. Cabiddu, A.; Canu, M.; Decandia, M.; Pompei, R.; Molle, G. The intake and performance of dairy ewes fed with different levels of olive cake silage in late pregnancy and suckling periods. Opt. Méditerr. 2004, 201, 197-201.

44. Chiofalo, B.; Liotta, L.; Zumbo, A.; Chiofalo, V. Administration of olive cake for ewe feeding: Effect on milk yield and composition. Small Rumin. Res. 2004, 55, 169-176. [CrossRef]

45. Mouhaddach, A.; El Hamdani, M.; Hassikou, R.; El Housni, A.; Zouahri, A.; Douaik, A.; Bendaou, M. Effect of cactus silage on the dairy performances of local ewes called Sardi. Opt. Méditerr. 2016, 115, 207-212.

46. Emery, R.S. Milk fat depression and the influence of diet on milk composition. Vet. Clin. N. Am. Food Anim. Pract. 1988, 4, 289-305. [CrossRef]

47. Abbeddou, S.; Rischkowsky, B.; Hilali, M.E.D.; Haylani, M.; Hess, H.D.; Kreuzer, M. Supplementing diets of Awassi ewes with olive cake and tomato pomace: On-farm recovery of effects on yield, composition and fatty acid profile of the milk. Trop. Anim. Health Prod. 2015, 47, 145-152. [CrossRef]

48. Gomes, L.C.; Alcalde, C.R.; Santos, G.T.; Feihrmann, A.C.; Molina, B.S.L.; Grande, P.A.; Valloto, A.A. Concentrate with calcium salts of fatty acids increases the concentration of polyunsaturated fatty acids in milk produced by dairy goats. Small Rumin. Res. 2015, 124, 81-88. [CrossRef]

49. Chilliard, Y.; Toral, P.G.; Shingfield, K.J.; Rouel, J.; Leroux, C.; Bernard, L. Effects of diet and physiological factors on milk fat synthesis, milk fat composition and lipolysis in the goat: A short review. Small Rumin. Res. 2014, 122, 31-37. [CrossRef]

50. Markiewicz-Kęszycka, M.; Czyżak-Runowska, G.; Lipińska, P.; Wójtowski, J. Fatty acid profile of milk-A Review. Bull. Vet. Inst. Pulawy 2013, 57, 135-139. [CrossRef]

51. Sanz Sampelayo, M.R.; Perez, L.; Boza, J.; Amigo, L. Forage of different physical forms in the diets of lactating Granadina goats: Nutrient digestibility and milk production and composition. J. Dairy Sci. 1998, 81, 492-498. [CrossRef]

52. Gravador, R.S.; Serra, A.; Luciano, G.; Pennisi, P.; Vasta, V.; Mele, M.; Pauselli, M.; Priolo, A. Volatiles in raw and cooked meat from lambs fed olive cake and linseed. Animal 2015, 9, 715-722. [CrossRef] [PubMed]

53. Lladó, V.; Terés, S.; Higuera, M.; Álvarez, R.; Noguera-Salva, M.A.; Halver, J.E.; Escriba, P.V.; Busquets, X. Pivotal role of dihydrofolate reductase knockdown in the anticancer activity of 2-hydroxyoleic acid. Proc. Natl. Acad. Sci. USA 2009, 106, 13754-13758. [CrossRef]

54. Lopes, L.S.; Martins, S.R.; Chizzotti, M.L.; Busato, K.C.; Oliveira, I.M.; Machado Neto, O.R.; Paulino, P.V.R.; Lanna, D.P.D.; Ladeira, M.M. Meat quality and fatty acid profile of Brazilian goats subjected to different nutritional treatments. Meat Sci. 2014, 97, 602-608. [CrossRef]

55. Gómez-Cortés, P.; Frutos, P.; Mantecón, A.R.; Juárez, M.; De La Fuente, M.A.; Hervás, G. Addition of olive oil to dairy ewe diets: Effect on milk fatty acid profile and animal performance. J. Dairy Sci. 2008, 91, 3119-3127. [CrossRef]

56. Sanz Sampelayo, M.R.; Chilliard, Y.; Schmidely, P.; Boza, J. Influence of type of diet on the fat constituents of goat and sheep milk. Small Rumin. Res. 2007, 68, 42-63. [CrossRef]

57. Abbeddou, S.; Rischkowsky, B.; Richter, E.K.; Hess, H.D.; Kreuzer, M. Modification of milk fatty acid composition by feeding forages and agro-industrial by-products from dry areas to Awassi sheep. J. Dairy Sci. 2011, 94, 4657-4668. [CrossRef]

58. Luciano, G.; Pauselli, M.; Servili, M.; Mourvaki, E.; Serra, A.; Monahan, F.J.; Lanza, M.; Priolo, A.; Zinnai, A.; Mele, M. Dietary olive cake reduces the oxidation of lipids, including cholesterol, in lamb meat enriched in polyunsaturated fatty acids. Meat Sci. 2013, 93, 703-714. [CrossRef] [PubMed] 
59. Mele, M.; Serra, A.; Pauselli, M.; Luciano, G.; Lanza, M.; Pennisi, P.; Conte, G.; Taticchi, A.; Esposto, S.; Morbidini, L. The use of stoned olive cake and rolled linseed in the diet of intensively reared lambs: Effect on the intramuscular fatty-acid composition. Animal 2014, 8, 152-162. [CrossRef] [PubMed]

60. Abidi, S.; Salem, H.B.; Vasta, V.; Priolo, A. Supplementation with barley or spineless cactus (Opuntia ficus indica f. inermis) cladodes on digestion, growth and intramuscular fatty acid composition in sheep and goats receiving oaten hay. Small Rumin. Res. 2009, 87, 9-16. [CrossRef]

61. Andreu-Coll, L.; Cano-Lamadrid, M.; Sendra, E.; Carbonell-Barrachina, Á.; Legua, P.; Hernández, F. Fatty acid profile of fruits (pulp and peel) and cladodes (young and old) of prickly pear [Opuntia ficus-indica (L.) Mill.] from six Spanish cultivars. J. Food Compos. Anal. 2019, 84, 103294. [CrossRef]

62. Hu, F.B.; Stampfer, M.J.; Manson, J.E.; Rimm, E.; Colditz, G.A.; Rosner, B.A.; Hennekens, C.H.; Willett, W.C. Dietary fat intake and the risk of coronary heart disease in women. N. Engl. J. Med. 1997, 337, 1491-1499. [CrossRef]

63. Enser, M. Producing meat for healthy eating. In Proceedings of the 46th International Congress Meat Science and Technology, Buenos Aires, Argentina, 27 August-1 September 2000; pp. 124-129.

64. Zampelas, A.; Paschos, G.; Rallidis, L.; Yiannakouris, N. Linoleic acid to alpha-linolenic acid ratio. In Omega-6/Omega-3 Essential Fatty Acid Ratio: The Scientific Evidence; Simopoulos, A.P., Cleland, L.G., Eds.; Karger: Basel, Switzerland, 2003 ; pp. $92-108$.

65. Simopoulos, A.P. The importance of the omega-6/omega-3 fatty acid ratio in cardiovascular disease and other chronic diseases. Exp. Biol. Med. 2008, 233, 674-688. [CrossRef]

66. Enser, M.; Hallett, K.G.; Hewett, B.; Fursey, G.A.J.; Wood, J.D.; Harrington, G. Fatty acid content and composition of UK beef and lamb muscle in relation to production system and implications for human nutrition. Meat Sci. 1998, 49, 329-341. [CrossRef]

67. Lovegrove, J.A. Dietary dilemmas over fats and cardiometabolic risk. Proc. Nutr. Soc. 2020, 79, 11-21. [CrossRef]

68. Malau-Aduli, A.E.O.; Siebert, B.D.; Bottema, C.D.K.; Pitchford, W.S. A comparison of the fatty acid composition of triacylglycerols in adipose tissue from Limousin and Jersey cattle. Aust. J. Agric. Res. 1997, 48, 715-722. [CrossRef]

69. Soyeurt, H.; Dehareng, F.; Mayeres, P.; Bertozzi, C.; Gengler, N. Variation of $\Delta 9$-desaturase activity in dairy cattle. J. Dairy Sci. 2008, 91, 3211-3224. [CrossRef] 